\title{
Resynchronising returns to service in anoestrous dairy cows in the South Island of New Zealand
}

\section{AJ Bates ${ }^{*}{ }_{1}$, AG Kenyon ${ }^{\dagger}$, RA Laven ${ }^{*}$ and J McDowell ${ }^{\#}$}

${ }^{*}$ Centre for Dairy Excellence, 20 Wilson Street, Geraldine 7930, New Zealand

tNorth Canterbury Veterinary Clinics, PO Box 58, Culverden 7391, New Zealand

抽stitute of Veterinary, Animal and Biomedical Sciences, Massey University, Private Bag 11222, Palmerston North, New Zealand

\# Vetlife Temuka, 35 King Street, Temuka 7920, New Zealand

sAuthor for correspondence. Email: andrew.bates@vetlife.co.nz

Supplementary Figure 1. Study design adopted during the trial for the use of the P4 Rapid assay (Ridegway Science, UK) and allocation of cows for re-synchronisation involving 1,819 cows on eight New Zealand dairy farms. 
